\title{
INFLUENCE OF GLOBAL SECURITY ENVIRONMENT ON COLLECTIVE SECURITY AND DEFENCE SCIENCE
}

\author{
Miroslav MITROVIC ${ }^{*}$ \\ ${ }^{1}$ Strategic Research Institute, University of Defence, Republic of Serbia
}

\begin{abstract}
Globalisation is a phenomenon which influences every aspect of contemporary life. Neo-liberal ideas lead to the multifunctional interdependence of geopolitics, the political economy, international relations, security, and defence issues. In the globalised world, many issues can be raised: Where are the roots of modern conflict? Who are the stakeholders in international relations? What are the dominant forms of contemporary conflicts? Do the forms of collective security fulfill the legitimacy of objectivity? What are the new challenges for modern defence science? Through the multidisciplinary approach, based on academic literature, as well scholars research papers, this work aims to contribute to the clarifying a rational approach to modern defence science in the contemporary, global security environment.
\end{abstract}

Keywords: Globalisation, defence science, international relations, global security, hybrid warfare, asymmetric threats

\section{Introduction}

Since globalization has had a continuum of philosophical ideas about global economic interdependencies, trade in commodities, intellectual and cultural exchange since the

* Corresponding author: mitrovicmm@gmail.com

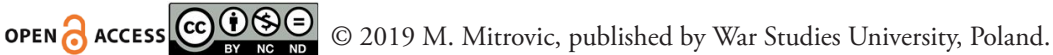

This work is licensed under the Creative Commons Attribution-NonCommercial-NoDerivatives 4.0 License. 
$16^{\text {th }}$ century (Wunderlich and Warrier 2010), neo-liberal understanding of political economy imposes its influence on comprehension of global security threats. According to Rosenau (Rosenau 1990), the world would see turbulent changes from the end of the twentieth century, particularly in:

- changing from an industrial to postindustrial order, focused on the technology which changes relationships, habits and social life structure;

- the emergence of issues which influence the global living environment, such as atmospheric pollution, terrorism, the drug trade, currency crises, contagious illnesses, etc.

- the reduced capabilities of states to produce satisfactory solutions for the political agendas, due to losing jurisdiction in some international issues, as well as the complicity of the new political-economic relations;

- fostering tendencies toward decentralisation;

- orientation towards groups of states or other collectives, based on interdependence and adjustments of new technologies.

Almost three decades after 1990, we are witnessing a world that has dramatically changed, with globalisation significantly influencing international relations. Globalisation and the development of a liberal interpretation of political economy has imposed its influence on the redefining of global risks. Global security risks make it necessary to define a common, global response to challenges to civilisation. Achieving this goal involves a need for common security awareness, which in ideal conditions involves the wider security community. The particular ideal form represents a free security community in which countries are subordinated to each other in the frame of standardised security values, and voluntarily involve efforts in the fight against common security threats. This type of security organisation requires methodically developed security management, achieved in accordance with democratic, universal and impartial forms of governance. But is such an ideal form of security governance possible in contemporary global relations? And what is the relationship between globalisation and global security?

Globalisation has a decisive importance in the understanding of the relationship on the international scene since the Cold War. The areas of social life which are the starter drivers, but also the endpoints of each of the global activities, are international economics and politics. The redefinition of relations in these areas fundamentally affected the world in the second half of the twentieth century and continues to expand in the twenty-first century. It could be said that we are witnesses to the benefits, but also, negative results of globalisation. Therefore, in consideration of globalisation and its impact on all spheres 
of society and thus security and defence, it is necessary to take a comprehensive, sober and rational approach. The essential driving forces of globalisation come from liberalism (Turner 2008), which has been confronted with a realistic approach to maintaining the integrity of the nation-state as an entity, and was transformed into neo-liberalism, the prevailing ideology of the Western world, or states with a so-called, developed democracy (Pečujlić 2002). Founded on an economic expansionistic approach, globalisation could be defined as a living process that is in progress, conditioned by market forces, and is not a policy-driven activity (Mittelman 1996, p. 3). From this point of view, it could be concluded that political changes at the global level are driven by market and economic developments, managed by economic goals and the interests of global institutions. Economic globalisation is in fact the driver for other forms of planetary phenomena such as geopolitics, geo-economics, and geo-energetics.

Globalisation has caused a separation of the concepts of international and global economy. The international economy represents an institutional approach, where the actors are states or international organisations, while the world economy provokes interest correlation of non-state (supranational) subjects (mostly corporations). Thus, the reality is bridging the impact of the nation or state with international, cross-border control (Cox 1996, pp. 22-23). The world economy is developing on account of the territorial fragmentations of the international economy, which enables the creation of a favourable environment for capital enlarged by exploiting "newly conquered" territories that were parts of the international economy.

Certain nations with their own heritage, ethical and moral norms, have different reactions to globalisation. Xenophobia, fear of losing their own identity, a sense of utilisation, the emergence of neo-colonialism, manipulation and subordination to foreign interests are some of the subjective feelings that the nations of the "third world", and also former communist countries could develop as a reaction to the impact of globalisation (Stenning, Smith, Rochovská, and Swiatek 2010). Resistance to globalisation by some nations looking to preserve their identities, leads to a complex category of relationship. Namely, globalisation depends on the relationship between nations with a distinguished level of development and the full complexity of relationships that could be set off. This can manifest itself as fertile crossbreeding and mutual enrichment or in a conflict, or a war of civilisations (Huntington 1996). The internal impact of globalisation on a single society as well as the establishment of standards and rules of manners, new values, particularly post-conflict, and systems with underdeveloped democracy, indicate 
of the need for a new approach to conflict resolution (Ivaniš et al. 2015), a common approach to the risks and threats, value-founded selection and strengthening of national identity which is not in conflict with others and strengthening civil society (Rosenau 1995b). The complexity of the phenomenon of globalisation suggests that dualism exists, expressed in economic, cultural and political spheres (Pečujlić 2002). The economic aspect implies the existence of two contradictory phenomena of globalisation: economic efficiency (superiority) and social inferiority. In communicational terms, technologysupported globalisation favours the model of sensation which could be called "citizen of the world". Namely, every particular individual connected by TV or Internet has the subjective impression of being affected by all global information, no matter where it takes place on the planet. Globalisation also involves a dialectical paradigm, with the growth of democracy and human rights, but at the same time, the rise of an authoritarian state as a form of transnational governance. Global institutions (the UN, NATO, and $\mathrm{EU}$ ) indicate supremacy of authority in a political decision, exempt from the legitimacy of the nation-state. In summary, it could be said that globalisation is marked by the neoliberal approach and it is an essential feature of globalisation, its duality: a comparative progression and regression. Characteristics of globalisation which could become conflicts include: (1) social polarisation in states and increasing differences between countries (rich and poor, developed and underdeveloped); (2) interfering in the sovereignty of states and subordinating them to supranational organisations; and (3) social fragmentation and the creation of political elites based on economic power (Cox 1996, p. 27). At the same time, the complexity of the processes on the international economic scene points to involvedness and repercussions for international relations (Moss 2005). Some features of global governance policy are: (1) relocation of management authority in the context of integration and fragmentation, as well as dispersion of international political authority in different directions and levels (sub-national, trans-national, international and global) (Rosenau 1995a); (2) simultaneous, immediate and complex interaction of social phenomena over a longer period of time (Hewson and Sincler 1999, pp. 3-23); and (3) restructuring the political economy, the organisation of the business and political elite. According to Pečujlić (2002), the main global security risks are: (1) the danger of ecological disaster; (2) the danger of nuclear, biological and chemical weapons; (3) the malignant growth of poverty and conflicts of civilisations; and (4) global terrorism. To contribute to an understanding of global security challenges a question can be asked: What are the challenges and risks and how do we respond to global threats? 


\section{Conditionality of Globalisation and Global Security}

Contemporary international relations indicate that discussion of the necessity for security communities, security management, defining global challenges and threats, polarisation, the choice between collective and national (individual) security, cannot be separated from the overall global approach to general social issues., Economics, market, technology, mass communication have a deep impact on the setting of national identity and understanding of development and security in the early decades of $21^{\text {st }}$ century. Understanding globalisation through changes in the global economy from mainly an American and the Western standpoint based upon the idea of "...democracy, as the best way of organising political life and the free market, as an essential tool for wealth creation" (Nye 2006, p. 72), without involving the presence of complex relationships on a macro and microeconomic level, significantly leads to conflicts of interest (Goncalves, Alves, Frota, Xia, and Arcot 2014). Furthermore, the economy is not per se ideal for wealth and fruitful living, and it should provoke globalisation regarding education, morality, nation, future, history, capitalism, and common sense reason for living (Cazdyn and Szeman 2011) or even "cosmopolitan culture" (Niezen 2004). In a political sense, the correlation between the theory of neo-liberalism and the relationship to peace as the absolute ambiance of the development of a contemporary democratic society could be illustrated by analysing the neo-liberalism genesis: (1) responsibility of democratic governments towards their citizens; (2) democratic political systems based on interdependence and control; and (3) peaceful resolution of disputes in the internal political scene (Lucarelli 2002, pp. 11-14). This reversible political process, the connection between democracy and free trade, on the one hand, and peace on the other, projects the ideal and forms the essence of a liberal model. But, also, the existence of a reflex to "radical democracy" in the form of "post-ideological anarchical politics" (Curran 2007) or a reaction such as "political Islam" (Springborg 2009) cannot be underestimated.

In the sense of global economic security risks, globalisation recognises economic crises as a legitimate reaction of a free and deregulated global economy. This contemporary point of view sees globalisation in a conflict context with expressed asocial and repressive tendencies, with potential for the development of new inequalities, creating a growing gap between the rich and the poor, the potential legalisation of violence, war and interventions (Fraile 2010; Čaušević 2017). The globalisation which emerged from the global market can be seen in a non-idyllic context, and is the driver of many inequality 
based crises (Suranovic 2010). That globalisation and neoliberalism have had a violent nature since 1990 can be seen in the fact that although the number of regimes classified as autocratic have been reduced twofold, the figure for conflicts has doubled at the same time. The aggregate economic and financial cost of conflicts was estimated to be $\$ 14.3$ billion in 2014, or $13.4 \%$ of the global economy (Marc 2016), which has led to the economy and financial interest being connected with global conflicts.

Since the processes of globalisation cannot be stopped, the essential question is not how to end this process, but through which political arrangements the problematic effects of contemporary globalisation could be mitigated and its desirable effects accelerated. More ideas are emerging that contemporary problems cannot be solved at the level of national societies and global processes must be taken into account for their adequate solution. Therefore, the state and international governance system imply the ability of the national state to cooperate and make partnerships. The global context of reality seems to aware of international agreements to solve transnational problems, such as economic and financial instability, legal and illegal migration, competition for natural resources, humanitarian and ecological crises, terrorism, drugs and arms trafficking, regional conflicts and threats in Cyberspace. Globalisation highlights all forms of cross border movement, which raise a risk of border porosity against all forms of hybrid and asymmetric threats (terrorism, environmental pollution, epidemics, political unrest, conflicts, computer viruses, etc.) and erases differences between internal and international security issues. Because of that, globalisation could be recognised as the catalyst for new, hybrid security threats (Mitrović 2017c).

\section{Contemporary Global Security challenges}

In last two decades, due to the impact of globalisation and the vanishing of general ideological differences, the previous geopolitical scene disappeared, as well as conditions for the prevailing of traditional warfare, which opened the arena for non-linear, hybrid and asymmetric threats. The geopolitical environment, conducted with a collision of ambitions and interests of out-of-state power centres, which through institutions of a state, international or non-governmental organisations express their interest, potentially leads to conflicts. General characteristics of contemporary conflicts are low intensity 
and unspecific forms of exposure. In academic and analytical comments, actual security threats and risks are frequently termed as hybrid security threats.

Hybrid security threats or hybrid warfare represent the actual expression of primeval aspirations of the strategic advantages over an opponent, mainly by non-armed means (Tzu 2000, p. 9). The analysis of contemporary conflicts concludes that they have the characteristics of emerged forms of the fourth (Renz and Smith 2016), or even fifth generation of wars (Mitrović 2017a). Lind (1989) announced a hybrid concept of conflict as future wars in which the dominant weapon will be media and the main target the enemy population's support of its government. In advance, all activities that lead to the destabilisation of the country or a change to its government, with the aim of establishing a disturbance of the balance in international relations and the achievement of the state's own interests, predominantly by non-combat means, can be termed as a hybrid (Kofman and Rojansky 2015, p. 5). Furthermore, hybrid security threats present synergy implementation of conventional weapons, unconventional and irregular tactics, terrorist acts and criminal activities, simultaneously acting on one battlefield, with the goal of achieving political objectives (Hoffman 2007). Hybrid security threats are generated to establish the conditions, which disrupt the balance of power in international relations and the achievement of its own interests, predominantly by non-combat means (Kofman and Rojansky 2015, p. 3). This concept of achieving national interests is called unconventional, political (hybrid) warfare (Hoffman 2016). Modern military doctrines recognise that contemporary conflicts in the global security environment cannot be solved only by military means, and in order to achieve success, it is necessary to engage all national capacities: diplomatic, informational, military and economic (DOA 2008). Russian military doctrine (President of Russian Federation 2010), recognises modern warfare as an integrated engagement of military forces and resources which have no military character, with an emphasis on the application of information warfare with the goal of achieving political objectives without the direct involvement of military forces, with the aim of shaping the desired response of world public opinion. Furthermore, the Russian doctrine predicts a specific form of modern conflicts in which they will apply the integrated operation of military and political, economic, informational and other non-military activities (President of Russian Federation 2014). Taking into account the characteristics and manifestations of hybrid forms that endanger national security, a summary of hybrid operations could be (Mitrović 2017b): 1) special and psychological operations, which represent the armed, conventional-unconventional forms of the engagement of forces and resources; 2) economic, energy and political 
pressures; 3) information campaigns with the aim of affecting public opinion; and 4) public diplomacy with the purpose of non-hosted foreign policy beyond traditional diplomacy. All listed forms of activities have the purpose of destabilisation of a country are organised and carried out with the purpose of achieving the strategic interests of the outer power centres, with the aim of establishing a state of disruption of balance in international relations, and the achievement of their own interests, mostly by noncombat means. On the basis on these theories, it could be concluded that hybrid warfare does not mean warfare per se (Vračar 2017), but a form of the concept of conflict in which a wide range of military and non-conventional activities are applied with the purpose of achieving strategic advantages for entity applying them.

Asymmetric security threats; according to some theories, asymmetry principles in warfare are as old as war itself and belong to mankind's warfare history (Metz and Johnson 2001). The same scholar thinks the asymmetric warfare concept is recognised as the possibility of a weaker opponent to achieve significant losses to the other, stronger side, with the simultaneous promotion of results with the purpose of mobilisation of new members (Renz and Smith 2016, p. 5). Asymmetry in the contemporary security environment could be recognised through the un-proportionality in the technical development of conflicted parts, an imbalance of moral power and the psychological readiness of units as well as of the wider population in organising, technology, asymmetry in war perseverance and other prerogatives, which are mostly dependent on socialpsychological characteristics of conflicted parts (Renz and Smith 2016, p. 10). Some authors (Lambakis and Kolet 2002), in summarising the asymmetric security threats, indicate their determinants as:

- new, unorthodox, unusual, surprising and unexpected threats;

- the presence of ultimately new and flexibly developed tactics and capabilities, as well as unconventional technical goods and arms.

- a globalised security environment with state and understate security subjects and stakeholders;

- non-linear and complex positions and altitudes of security subjects in global international relations and security issues;

- an inappropriate organisational and doctrinal approach of the state and under state stakeholders;

- latent institutional weaknesses of a state system of defence, especially in the area of prevention and protection development. 
Hybrid warfare and asymmetric security threats are very close and they mark the contemporary global security environment. The common point of analysis of both phenomena could be raised upon Hart's (Hart 1954) view of a winning strategy recognised as an indirect approach with different forms of unarmed means, which effectively demolish the psychological and psychical balance of an opponent and lead to his defeat. The logic of hybrid and asymmetric warfare can basically be recognised through the Chaos and Network-centric theories of conflict management (Korybko 2015; Darius 2014; Shahskov 2011; Mann 1992). In addition, the network-centric warfare theory is also in correlation with hybrid and asymmetric endangerment of security, relying upon modern technologies, cyberspace networks and soft power mechanisms (Arquilla and Ronfeldt 2001; Cebrowski and Garstka 1998). Through the analyses of subjects, determinants, as well areas and aims of acting (Mitrović 2017a), it could be concluded that hybrid and asymmetric warfare closely correlate in areas of conceptual approach of conflict management, acting subjects (which aren't predominantly state centralised), flexibility, adaptability, unconventionality, means and methods, ways of acting, choosing of targets, communication strategy, mobilisation of supporters and new members. Hybrid as well as asymmetric security endangerment act mostly on the most vulnerable, critical society components, resources or infrastructures that we consider wider socio-psychologically, economically, and politically components or more concrete acts against elements of infrastructure, personal safety and daily life activities, with psychological effects afterwards (Mitrović 2018). From all of the above, it could be concluded that hybrid and asymmetric endangerment of security is either not a new phenomenon or has been achieved through globalisation.

\section{Collective agreement on global threats - rational choice or creating a "Global Ruler"}

The contemporary security paradigm raises these issues: Does the collective defence model have an answer regarding global security threats? The position of global threats with the dialectical dualism of the contemporary globalisation movement leads to complex reactions from marginalised or vulnerable groups, individuals and nations. Whether it is a terrorist or criminal organisation model, an individual or group, proxy extremist movements, they strive to express their frustration and draw attention to their 
goals in order to improve their position. National defence has a strategic approach, is defined by laws and strategic documents and is an instrument of foreign policy. Integration is imposed by a common response to security threats, challenges, and risks, and looks like a rational path for a nation that strives for the ideals of the open security community. The existence of common, global threats inevitably leads to the existence of a collective response to the supposed threats, challenges, and risks. Collective conflict management (CCM) "is a form of joint action that can be taken from the global or regional organisations or temporarily formed alliances in response to conflict or to prevent or stop the conflict, regardless of whether it originated within the state or an interstate conflict" (Lepgold and Weiss 1998, p. 5). So CCM is a systematic and organised effort to avoid, prevent, or stop acts disturbing peace with a wide range of common actions involving collective security, various multilateral forms of establishing and maintaining peace and stability. However, a question about the objectivity of the supranational authority that will assess that global security is distinguished. The allocation of an individual nation's legitimacy regarding the decisions regarding the security problem opens a potential area for powerful stake-holders institutions to have an influence regarding the objectivity of crisis assessments. It is important to note that CCM creates the possibility that allows powerful and influential countries to create an environment in which some regime or state could be represented as "dangerous" for the rest of the world. From this position, an institution of CCM could be used as a tool for the success of dominant stakeholders, sometimes against international law and by using hybrid or conventional types of action. Therefore, in ideal circumstances, it is necessary to achieve several principles, which involve the realisation of a "critical mass" in the international environment, due to the granting of supranational legitimacy to CCM. Nevertheless, at some point, it is almost a "mission impossible" task, because of the core of CCM being based on a globalisation legacy, in other words on the interest of power elites (Nye 2006). In summary, the characteristics of collective conflict management can be summarised as follows (Lepgold et al. 1998, p. 9):

1. Since international institutions express the balance of power, they have no independent approach to resolving the conflict.

2. Collective conflict management is jeopardised by the over-engagement of large and powerful states.

3. Cooperation in the implementation of the concept of collective conflict management is very fragile if there is no form of binding contract between the parties. 
4. In accordance with the orientation towards common goals, conflict management is collectively insensitive to individual national interests.

5. Collective conflict management has the greatest effects when applied in the preconflict phase as prevention in the phase of conflict prevention and it is becoming a conflict.

6. The most powerful tool of preventive diplomacy is a pragmatic interest-driven process of negotiation.

The interest of each state determines and recognises the fact that the institutional, international approach to collective action leads to cost reduction of individual responses to threats. The results and effects include a synergistic performance of all participants, respect for procedures and rules, decision-making consensus, objectivity in approach etc. Although it is difficult to achieve this ideal form of international response to the conflicts that occur globally, it must be noted that this approach to solving security challenges and threats is most effective. In order to achieve maximum results, it is necessary to accomplish common attitudes regarding politics and the achievement of strategic interaction among different factors. Compatibility of participants and their characteristics is necessary, as well as the correlation of their relative power. The actors need to have an appreciation of the nature of the relationship, as well as to encourage faith in the importance of developing the relationship of trust and cooperation. It is necessary to have the ability to perceive the future, they have a vision of the political goals for which the actors are in favour and the links to international politics and political beliefs and regulations within states (Lamborn 1998, p. 31-54). If we consider that in a general overlay of resources, technical support and information exchange, collective defence has a primary role, interoperability has unique importance for achieving the effectiveness of common efforts. The existence of active interdependence in all spheres of life on a global scale, wiping clear boundaries between the state and a compromising security of "free" entities, as well as the escalation of asymmetric and hybrid challenges, indicate the need to adapt security and defence science and the global approach to security. The inevitability of finding an adequate multidisciplinary approach of defence, political, social, demographic, technological, and other aspects is recognised as a rational response to contemporary global security challenges. The science is also imposed as a capital resource and a factor in society's development and the link between scientific knowledge and the application of these findings in practice is negligible. Although there is intensive scientific research, the implementation of the research findings is not sufficiently developed and applied in practice. Why is this necessary? 
Compared to the Cold War period when the role of the armed forces was primarily reflected in the defence of territory, this role has been extended today to the changing nature of keeping operations throughout the world as sort of the diplomacy and defence matters of internal security. Certainly, the issue of defending national territory has not become obsolete or irrelevant, but new security challenges include the projection of forces for warfare and peacekeeping and humanitarian missions, internal state security issues, participation in the construction of national states and helping civilian authorities. These changes have caused significant organisational, financial and doctrinal demands, and making difficult decisions about the further development of the armed forces. The very same armed forces have undergone many significant changes in line with global demands (Edmunds and Malešič 2005):

- Professionalisation, which included the termination of mandatory military service, voluntary service, and high professional standards.

- Functionality, with a contemporary demand for non-traditional missions (peace missions, humanitarian interventions, and crisis management).

- Internationalisation of missions in a multinational context.

- Strengthening the legitimacy of the state.

- Reducing the motivation for joining the professional armed forces due to the insufficient competence of the military profession.

- Reducing the social role of the armed forces.

- Increasing cooperation in civil-military relations, especially in the fields of training, education, and logistics.

New hybrid and asymmetric challenges have a completely different structure than those that threatened stability and security during the Cold War, which posed the issue of reconceptualisation of the notion of security itself. The defence science at the beginning of the $21^{\text {st }}$ century needs to adapt its research to a cooperative approach across the spectrum of multidisciplinary scientific fields that need to intellectually contribute to the maintenance of stability and security in the world. 


\section{Conclusions}

A globalised world requires an adequate response to contemporary security threats. The position of small post-communist countries is obsolete, economically and geopolitically approved, with mandatory developed legitimacy and legality procedures. Safety assessments are not limited to the identification of potential military threats in the future but are also focused on the comprehensive analysis of trends in the areas of importance for the global, regional and national security. Contemporary understanding of security put in front of the armed forces requires the development of additional abilities for adequately responding to asymmetric and hybrid threats. Defence sciences are expected to indicate ways of responding to the contemporary forms of the identified threats to national and global interdependence caused by the transnational and supranational approach to all segments of society and global security threats. This approach also includes the provision of an adequate scientific base to support the contemporary struggle against new threats. The harmonisation of classical and contemporary approaches to defence science should promote the development of a new theoretical view of globalisation, as well as the applicability of a response to the fight against contemporary security challenges, risks, and threats. In the development and reaffirmation of defence science, it is necessary to generate ideas, stimulate an analytical approach, encourage critical thinking and conduct expert discussions on all aspects of adapting to new security challenges and security and defence aspects of foreign policy, international relations, military cooperation, military technology transfer, etc.

\section{References}

Arquilla, J., and Ronfeldt, D., 2001. Networks and Netwars: The Future of Terror, Crime, and Militancy. Santa Monica, CA: Rand.

Čaušević, F., 2017. A Study into Financial Globalization, Economic Growth and (In)Equality. Palgrave Macmillan.

Cazdyn, E., and Szeman, I., 2011. After Globalization. Blackwell Publishing.

Cebrowski, A., and Garstka J., 1998. Network - Centric Warfare: Its Origin and Future. U.S. Naval Institute.

Cox, R.W., 1996. Perspective of Globalization. In: Mittelman, J.H., ed., Globalization-critical reflections. London: Lynne Rienner Publisher. 
Cull, N. 2006. Public Diplomacy Before Gullion: The Evolution of a Phrase. [online]. USC Center on Public Diplomacy. Available from https://uscpublicdiplomacy.org/blog/publicdiplomacy-gullion-evolution-phrase/ [Accessed 14 May 2017].

Curran, G., 2007. 21st Century Dissent Anarchism, Anti-Globalization and Environmentalism. New York: Palgrave Macmillan.

Darius, M., 2014. Iraq and Syria are Burning, 'Constructive Chaos' and America's Broader Strategy to Conquer Eurasia [online]. GlobalResearch.ca. Available from https://www. globalresearch.ca/iraq-and-syria-burning-a-collection-of-articles-about-constructive-chaosat-work/5388270 [Accessed 15 Mar 2019].

DOA - Department of the Army, 2008. Field Manual No. 3-0: Operations. Washington, DC.

Edmunds, T. and Malešič, M., 2005. Defence Transformation in Europe: Evolving Military Roles. Amsterdam: IOS Press.

Fraile, L., 2010. Blunting Neoliberalism Tripartism and Economic Reforms in the Developing World. Palgrave Macmillan.

Goncalves, M., Alves, J., Frota, C., Xia, H., and Arcot, R., 2014. Advanced Economies and Emerging Markets: Prospects for Globalization. New York: Business Expert Press.

Hart, L., 1954.The Strategy of Indirect Approach. Internet Archive. National War College.

Hewson, M.M. and Sincler, T.J., 1999. The Emergency of Global Governance Theory. In Hewson, M.M., and Sincler, T.J., eds, Approach to Global Governance Theory. New York: State University of New York Press.

Hoffman., F., G., 2016. On Not-So-New Warfare: Political Warfare vs. Hybrid Threats. [online]. War on The Rocks. Available from: http://warontherocks.com/2014/07/on-not-so-newwarfare-political-warfare-vs hybridthreats [Accessed 15 Mar 2019].

Hofman., F., G., 2007. Conflict in the 21st Century-The Rise of Hybrid Wars. Potomac Institute for Policy Studies.

Huntington, S.P., 1996. The Clash of Civilization-Remaking of World Order. Simon\&Schuster.

Kofman, M., Rojansky, M., 2015. A Closer look at Russia's 'Hybrid War', Kennan Cable No. 7, Woodrow Wilson International Center for Scholars.

Korybko, A., 2015. Hybrid Wars: the indirect adaptive approach to regime change. Moscow: Peoples' Friendship University of Russia.

Lambakis, S., Kiras, J., and Kolet, K., 2002. Understanding 'Asymmetric' Threats to the United States. Fairfax: National Institute for Public Policy.

Lamborn, A.C.,1998. Theoretical and Historical Perspectives on Collective Security. In Lepgold, J.,and Weiss, T.G., 1998. Collective Conflict Management and Changing World Politics. New York: State University of New York.

Lepgold, J.,and Weiss, T.G., ed. Collective Conflict Management and Changing World Politics. New York: State University of New York.

Lind, W., Nightengale, K., Schmitt, J., Sutton, J., Wilson, G., 1989. The Changing Face of War: Into the Fourth Generation. Marine Corps Gazette.

Lucarelli, S., 2002. Peace and Democracy: The Rediscovered Link The EU, NATO and the European System of Liberal-Democratic Security Communities, European University Institute: NATO Euro-Atlantic Partnership Council Individual Research Fellowships - 2000-2002.

Mann, S., 1992. Chaos Theory and Strategic Thought. Parameters. 
Marc, A., 2016. Conflict and violence in the 21st century [online]. United Nations. Available from: https:/www.un.org/pga/70/wp-content/uploads/sites/10/2016/01/Conflict-and-violencein-the-21st-century-Current-trends-as-observed-in-empirical-research-and-statistics-Mr-Alexandre-Marc-Chief-Specialist-Fragility-Conflict-and-Violence-World-Bank-Group.pdf [Accessed 30 Jun 2017].

Mitrović, M., 2017a. Hybrid warfare and asymmetric security threats. Vojno delo, Belgrade, 5.

Mitrović, M. 2017b. The economic and energy aspects of a hybrid threat to national security. Vojno delo, Belgrade, 6.

Mitrović, M. 2017c. Savremeni izazovi upravljanja nacionalnom bezbednošću u hibridnom bezbednosnom okruženju [Contemporary challenges of Management with National Security in Hybrid Security environment], Conference Proceedings-Economics and Management: Globalization Challenges, Conference EMAN 2017, Ljubljana, 716-721.

Mitrović, M., 2018 (in print). Critical National Infrastructure in the scope of Asymmetric Security Threats involved in Hybrid Warfare Concept. Asymmetry and Strategy. Belgrade: Strategic Research Institute.

Mittelman, J.H., 1996. The Dynamics of Globalization. In: Mittelman, J.H., ed., Globalizationcritical reflections. London: Lynne Rienner Publisher.

Moss, B., ed. 2005. Monetary Union in Crisis - The European Union as a Neo-liberal Construction. Palgrave Macmillan.

Niezen, R., 2004. A World Beyond Difference Cultural Identity in the Age of Globalization, Blackwell Publishing.

Nye, J., 1990. The misleading metaphor of decline. The Atlantic Monthly. March.

Nye, J., 2006. Understanding International Conflicts. Belgrade: Stubovi culture.

Renz, B., Smith, H., 2016. Russia And Hybrid Warfare-Going Beyond The Label, [online]. Finnish Prime Minister's Office, Government's analysis. Available from https://helda.helsinki.fi/ bitstream/handle/10138/175291/renz_smith_russia_and_hybrid_warfare.pdf?sequence $=1$ [Accessed 15 March 2019].

Rosenau, J.N., 1990. Turbulence in World Politics. New Jersey: Princeton University Press.

Rosenau, J.N., 1995a. Distant Proximities: Dynamics and Dialectics of Globalization. In: Hettne,

B., ed. International Political Economy: Understanding Global Disorder. London: Zed.

Rosenau, J.N., 1995b. Governance to the Twenty-first Century. Global Governance: A Review of Multilateralism and International Organisations 1, 13-43.

Shahskov, S., 2011. The theory of 'manageable chaos' put into practice. Strategic Culture Foundation, 1 Mar. 2011.

Sharma, S., 2008. Achieving Economic Development in the Era of Globalization. New York: Routledge.

Springborg, R., ed. 2009. Development Models in Muslim Contexts: Chinese, "Islamic" and NeoLiberal Alternatives. Edinburgh: Edinburgh University Press.

Stenning, A., Smith, A., Rochovská, A., and Swiatek, D., 2010. Domesticating Neo-Liberalism: Spaces of Economic Practice and Social Reproduction in Post-Socialist Cities. Blackwell Publishing.

Suranovic, S., 2010. A Moderate Compromise Economic Policy Choice in an Era of Globalization. Palgrave Macmillan.

Turner, R., 2008. Neo-Liberal Ideology History, Concepts and Policies. Edinburgh University Press. 
Tzu, S., 2000. Art of War-Chapter 3: Attack by Stratagem. Leicester: Allandale.

Vračar, M., 2017. Theoretical-epistemological approach in the study of the "Hybrid Warfare". Vojno delo, Beograd, 7/2017.

Wunderlich, J.,and Warrier, M., 2010. A Dictionary of Globalization. London:Routledge,

Ivaniš, Ž., Mitrović, M. and Mledenović, M., 2015. Conflict resolution on Western Balkans by Negotiation In Collection of paper $7^{\text {th }}$ International Congress „Ecology, health, work, sport, Banja Luka, 287-296

Pečujlić, M., 2002. Globalization-Two Worlds. Belgrade: Gutembergova galskija.

President of Russian Federation 2010. Military Doctrine of Russian Federation. Moscow.

President of Russian Federation 2014. Military Doctrine of Russian Federation [online]. Available from: http://www.consultant.ru/document/cons_doc_LAW_172989 [Accessed 15 Mar 2019].

\section{Authors:}

Miroslav Mitrovic, $\mathrm{PhD}$

Strategic Research Institute, University of Defence, Republic of Serbia

https://orcid.org/0000-0001-7541-8565 